\title{
PENGARUH MEREK, KUALITAS PRODUK, MEDIA SOSIAL DAN HARGA TERHADAP MINAT BELI KONSUMEN PADA PRODUK BRAND WARDAH
}

\author{
Yemima Marvell Geraldine ${ }^{1}$, Ari Susanti ${ }^{2}$ \\ ${ }^{1}$ Program Studi Manajemen, Sekolah Tinggi Ilmu Ekonomi Surakarta \\ ${ }^{2}$ Program Studi Manajemen, Sekolah Tinggi Ilmu Ekonomi Surakarta \\ yemima.ninoy12@gmail.com
}

\begin{abstract}
ABSTRAK
Tujuan penelitian ini adalah untuk mengetahui pengaruh citra merek, kualitas produk, media sosial dan harga terhadap minat beli konsumen pada produk Brand Wardah. Metode penelitian yang digunakan adalah dengan Non-Probability Sampling dengan spesifik menggunakan Convinience/ Accidental Sampling, dengan jumlah responden 100 orang. Berdasarkan penelitian yang telah dilakukan, pengambilan sampel menggunakan teknik Roscoe yaitu pengumpulan data berbasis kuesioner atau angket yang diserahkan kepada para responden melalui media sosial menggunakan Google Form. Alat uji yang digunakan dalam penelitian ini menggunakan SPSS 21 . Teknik pengujian instrumen menggunakan teknik uji Validitas dan Reliabilitas. Analisis data menggunakan uji Asumsi Klasik, analisis Linier Berganda, uji t, uji $F$, dan Koefisien Determinasi. Hasil penelitian menunjukkan bahwa citra merek $\left(X_{1}\right)$ tidak berpengaruh secara signifikan minat beli konsumen pada produk brand Wardah, kemudian kualitas produk $\left(\mathrm{X}_{2}\right)$ berpengaruh secara signifikan terhadap minat beli konsumen pada produk brand Wardah, selanjutnya media sosial $\left(X_{3}\right)$ berpengaruh positif terhadap minat beli konsumen pada produk brand Wardah, dan yang terakhir adalah harga $\left(\mathrm{X}_{4}\right)$ berpengaruh baik terhadap minat beli konsumen pada produk brand Wardah.
\end{abstract}

Kata Kunci: Citra Merek, Kualitas Produk, Media Sosial, Harga dan Minat Beli

\section{ABSTRACT}

The purpose of this study was to determine the effect of brand image, product quality, social media and price on consumer buying interest in Brand Wardah products. The research method used is NonProbability Sampling, specifically using Convinience/Accidental Sampling, with 100 respondents. Based on the research that has been carried out, sampling using the Roscoe technique, namely data collection based on questionnaires or questionnaires submitted to respondents through social media using Google Form. The test instrument used in this study used SPSS 21. The instrument testing technique used the Validity and Reliability test technique. Data analysis used Classical Assumption test, Multiple Linear analysis, $\mathrm{t}$ test, $\mathrm{F}$ test, and Coefficient of Determination. The results showed that brand image (X1) did not significantly influence consumer buying interest in Wardah brand products, then product quality (X2) significantly affected consumer buying interest in Wardah brand products, then social media (X3) had a positive effect on buying interest. consumers on Wardah brand products, and the last is the price (X4) has a good effect on consumer buying interest in Wardah brand products.

Keywords: Brand Image, Product Quality, Social Media, Price and Purchase Interest 


\section{A. PENDAhULUAN}

Perkembangan modernisasi saat ini sangat pesat mulai dari industri hingga pada bidang jasa. Siapapun yang tidak mengikuti zaman akan terlindas dengan modernisasi yang sangat cepat membawa perubahan dalam setiap aspek, baik perubahan positif maupun negatif. Segala jenis usaha juga terdampak oleh modernisasi dan mau tidak mau harus bisa beradaptasi dengan cepat mengikuti arus perubahan yang ada.

Perubahan tidak hanya terjadi pada sektor perusahaan semata melainkan juga mempengaruhi pola pikir dan kebutuhan serta keinginan konsumen. Sebagian besar konsumen saat ini telah "melek" akan adanya perubahan dan dengan cepat beradaptasi dengan perubahan tersebut yang berimbas pada sisi konsumtif mereka mulai dari kebutuhan pokok hingga tersier, bukan hanya percaya saja mengenai iklan suatu produk atau jasa melainkan konsumen sekarang ini lebih pandai dalam menilai suatu produk untuk kebutuhan keseharian mereka.

Perubahan dalam pola konsumtif konsumen mengharuskan perusahaan untuk giat berinovasi dan cermat dalam menilai dan mengetahui apa yang konsumen butuhkan serta inginkan. Perusahaan harus memiliki daya juang yang tinggi serta harus bisa mengerti kebutuhan konsumennya dengan baik, memiliki produk yang spesifikasi dan kualitasnya mumpuni namun harganya relatif terjangkau, karena konsumen saat ini sangatlah presisi dalam menentukan kualitas, harga dan brand apa yang bisa menarik perhatian di media sosial serta memiliki brand image atau citra merek yang baik dan mudah diingat.

Perusahaan kosmetik juga harus beradaptasi dengan keinginan konsumennya, tidak hanya mengikuti trend namun juga harus mengerti kebutuhan pelanggan. Citra merek yang dimiliki perusahaan harus berada pada posisi "top of mind" bila ingin bersaing dengan kompetitor dan menjadi pilihan pertama konsumen. Citra merek adalah nilai brand tersebut dalam benak konsumen, seperti apapun itu citra yang dimiliki oleh suatu merek akan sangat mempengaruhi minat beli seseorang. Selain itu kualitas produk juga tolok ukur konsumen dalam memilih produk, karena produk yang berkualitas memiliki nilai lebih di mata konsumen. Perusahaan kosmetik juga gencar melakukan pemasaran dengan media sosial karena media sosial berperan penting dalam pengenalan suatu produk dinilai dari banyaknya pengguna media sosial saat ini. Banyaknya produsen kosmetik sekarang ini membuat persaingan harga semakin ketat dan sebagai konsumen yang "pintar" seringkali membandingkan bukan hanya dari segi citra merek dan kualitasnya namun juga dari sisi harga karena bagi konsumen, produk yang menarik adalah yang berkualitas dan harganya terjangkau.

Wardah adalah salah satu brand kosmetik/makeup lokal yang paling diminati 
oleh konsumen di Indonesia, terlihat dari beberapa artikel yang menunjukkan bahwa Wardah memiliki peminat yang lebih banyak dibanding brand lain dan menjadi brand makeup lokal dengan pencarian teratas. Paling diminati daripada brand lokal lainnya karena brand Wardah memiliki keunggulan dalam setiap produk yang ditawarkan dengan ciri khasnya yaitu produk berlabel "Halal" yang menjadi citra baik di mata masyarakat. Kemudian Wardah dinilai mampu bersaing dengan produk-produk kosmetik dari luar negeri dan juga sering memberikan promo dalam kegiatan promosinya baik dilakukan lewat media online atau "social media" maupun di konter penjualan milik Wardah yang sangat menarik perhatian kaum hawa karena disamping promosi yang baik, Wardah juga mematok harga yang terbilang terjangkau untuk kategori kosmetik berkualitas yang cukup bersaing dengan brand lokal maupun internasional.

Berdasarkan data yang peneliti peroleh dari Google Trends tahun 2019-2020 membuktikan bahwa brand kosmetik Wardah menjadi brand dengan pencarian rata-rata sebanyak $75 \%$ dari keseluruhan pencarian mengenai brand kosmetik lokal, baru diikuti oleh brand Emina, Purbasari, Sariayu dan La Tulipe. Kemudian menurut NewsLab UAJY tahun 2018, brand makeup lokal yang paling banyak diminati di Indonesia adalah Wardah yang menduduki peringkat nomor satu dengan jumlah persentase sebesar $23 \%$ dari keseluruhan data, kemudian diikuti oleh brand Make Over, Emina, Purbasari dan lain-lain. Terakhir menurut GDILAB.com tahun 2017 menunjukkan bahwa brand kosmetik yang paling dibicarakan di Twitter adalah brand Wardah karena dari 1490 post, Wardah menjadi peringkat pertama dengan 500 post, lalu ada brand Sariayu, Emina, Purbasari dan Mustikaratu, dan Wardah juga menjadi kontributor pertama di Twitter dengan 411 kontributor dari total 985 kontributor, setelah itu diikuti oleh brand Purbasari, Emina, Sariayu dan terakhir adalah Mustikaratu.

\section{B. METODE}

\section{Metode Pengumpulan Data}

Metode Kuantitatif merupakan teknik yang diterapkan pada penelitian ini. Penelitian kuantitatif adalah mekanisme untuk mengetahui data-data yang berwujud angka sebagai alat penyelidikan mengenai hal suatu hal yang sedang diteliti. (Kasiram, 2008).

\section{Populasi dan Sampel}

Pengertian populasi yaitu bagian umum yang tersusun dari obyek dan atau subyek yang terdiri dari karakter dan nilai tertentu yang dijadikan patokan peneliti dan kemudian dipelajari dan mengambil kesimpulannya. (Sugiyono, 2005). Sedangkan sampel adalah sebagian obyek yang diambil dan diteliti serta merupakan perwakilan dari keseluruhan populasi. (Soekidjo, 2005). Berdasarkan penelitian yang variabel terikatnya dipengaruhi oleh 
beberapa variabel bebas, maka Analisis Regresi Berganda menjadi sistem yang di aplikasikan pada penelitian ini (Nazir, 2013). Nilai sampel ini ditentukan menggunakan rumus teori Roscoe. Teori Roscoe (Sugiyono, 2015) berkata bahwa format sampel yang mumpuni untuk menunjang penelitian adalah berkisar dari 30 hingga 500 sampel. Berdasarkan pemaparan itu, maka sampel yang digunakan adalah 100 sampel.

\section{Jenis dan Teknik Pengumpulan Data}

Penelitian ini berbasis data primer. Data primer merupakan data yang dihimpun oleh peneliti, bisa berupa tanya jawab, rekam jejak serta dalam bentuk lainnya (Suharsimi Arikunto, 2013). Cara yang digunakan untuk menghimpun data adalah dengan menyebarluaskan angket atau kuesioner yang melalui media sosial yang dimiliki oleh peneliti. Sumber data yang terkumpul merupakan pengguna media sosial dan memiliki minat terhadap produk kosmetik Wardah. Penggunaan kuesioner sebagai bentuk mengumpulkan data dengan cara memberi kuis atau gagasan tertentu kepada sejumlah orang untuk dijawab (Sugiyono, 2013).

\section{Teknik Analisis Data}

Peneliti akan menggunakan beberapa tahap pengujian seperti, Uji Instrumen Data (Uji Validitas dan Uji Reliabilitas), Uji Asumsi Klasik (Uji Normalitas, Uji Multikolinearitas, Uji Heteroskedastisitas), dan Uji Hipotesis
(Uji Linier Berganda, Uji t, Uji F, dan Koefisien Determinasi).

\section{HASIL DAN PEMBAHASAN}

Penelitian ini memiliki karakteristik responden berdasarkan Umur terdiri dari $<17$ thn (4\%), 17-30 thn (78\%) dan >30 thn (18\%). Jenis pekerjaan Mahasiswa (50\%), PNS (10\%) ,Wirausaha (14\%), Karyawan Swasta (26\%) dan Lainnya (10\%) serat domisili berasal dari Solo (30\%), Surabaya (20\%)I Lainnya (50\%).

Selanjutnya hasil penelitian yang dilakukan menghasilkan sebagai berikut:

\section{Uji Instrument Data}

\section{a. Uji Validitas}

Berdasar dari output SPSS, maka diketahui bahwa nilai $r$ tabel dengan jumlah $\mathrm{N}$ adalah 100 dengan tingkat signifikan 0,05 pada distrbusi nilai $r$ tabel adalah 0,1966 maka hasil output uji validitas SPSS diketahui semua $r$ hitung variabel dinyatakan $\leq r$ tabel. Jadi dapat ditarik kesimpulan bahwa keseluruhan variabel dinyatakan valid.

\section{b. Uji Reliabilitas}

Berdasarkan hasil dari uji reliabilitas menggunakan SPSS, maka diketahui $X_{1}$ sebesar 0,846 kemudian $X_{2}$ sebesar 0,884 lalu $X_{3}$ sebesar 0,740 
lalu $\mathrm{X}_{4}$ sebesar 0,807 dan $\mathrm{Y}$ sebesar

0,783 , sehingga keempat variabel tersebut reliabel.

\section{Uji Asumsi Klasik}

\section{a. Uji Normalitas}

Bersumber dari hasil penghitungan SPSS uji Kolmogorov-Smirnov, maka dapat ditemukan bahwa hasil nilai sig adalah 0,297 $\geq 0,05$ yang berarti nilai tersebut mempunyai nilai residual yang berdistribusi normal.

\section{b. Uji Multikolinearitas}

Mengacu pada perhitungan SPSS, maka dapat diketahui hasil tolerance $X_{1}$ sebesar $0,449 \geq 0,1$ dan nilai VIF variabel $X_{1}$ sebesar 2,229 $\leq$ 10. Lalu variabel $X_{2}$ dengan nilai tolerance sebesar $0,455 \geq 0,1$ dan nilai VIF $2,197 \leq 10$. Kemudian variabel $X_{3}$ dengan nilai $0,961 \geq 0,1$ dan VIF $1,041 \leq 10$. Selanjutnya variabel $\mathrm{X}_{4}$ dengan nilai $0,973 \geq 0,1$ dan VIF $1,028 \leq 10$, sehinga keempat variabel tersebut dapat disimpulkan tidak terjadi Multikolinearitas.

\section{c. Uji Heteroskedastisitas}

Menitikberatkan pada hasil hitung SPSS, nilai sig variabel $X_{1}$ sebesar $0,417 \geq 0,05$ yang artinya tidak terjadi Heterokedastisitas. Lalu pada variabel $X_{2}$ dengan nilai sig sebesar $0,612 \geq 0,05$ sehingga Heteroskedastisitas tidak terjadi. Kemudian variabel $X_{3}$ dengan nilai $0,880 \geq 0,05$ sehingga tidak terjadi Heteroskedastisitas. Terakhir, variabel $X_{4}$ dengan nilai $0,383 \geq 0,05$ sehingga Heteroskedastisitas tidak berlaku.

Tabel 1. Hasil Uji Regresi Berganda

\begin{tabular}{lc}
\hline Variabel & Unstandardized Beta Coefficients \\
\hline Constant & $-2,945$ \\
\hline Citra Merek $\left(X_{1}\right)$ & 0,208 \\
\hline Kualitas Produk $\left(X_{2}\right)$ & 0,165 \\
\hline Media Sosial $\left(X_{3}\right)$ & 0,273 \\
\hline Harga $\left(X_{4}\right)$ & 0,196 \\
\hline
\end{tabular}

Sumber : Data primer yang diolah (2021) 


\section{a. Uji Regresi Linier Berganda}

Berdasarkan tabel di atas, nilai regresi linier berganda mendapatkan hasil sebagai berikut :

$$
\begin{aligned}
Y= & -2,945+0,208 X_{1}+0,165 X_{2}+ \\
& 0,273 X_{3}+0,196 X_{4}
\end{aligned}
$$

Penjabaran persamaan regresi liner berganda adalah :

1) Konstanta sejumlah $-2,945$ yang berarti apabila variabel bebas Citra Merek $\left(\mathrm{X}_{1}\right)$, Kualitas Produk $\left(\mathrm{X}_{2}\right)$, Harga $\left(X_{3}\right)$ dan Media Sosial $\left(X_{4}\right)$ tidak mengalami perubahan, sehingga minat beli konsumen terhadap produk kosmetik brand Wardah menurun sejumlah 2,945.

2) Nilai koefisien Citra Merek sebesar 0,208 yang berarti berpengaruh positif, ditandai dengan jika citra merek meningkat maka minat beli konsumen pada produk brand Wardah mengalami peningkatan sebanyak 0,208
3) Nilai koefisien Kualitas Produk sebesar 0,165, artinya setiap kualitas produk meningkat maka akan diikuti dengan meningkatnya minat beli konsumen pada produk brand Wardah sebanyak sejumlah 0,165 .

4) Nilai koefisien Media Sosial sebesar 0,273 yang artinya setiap adanya peningkatan dalam aspek media sosial maka akan diikuti dengan meningkatnya minat beli konsumen pada produk brand Wardah sebanyak sejumlah 0,273.

5) Nilai koefisien Harga sebesar 0,196 yang artinya bila variabel harga mengalami perubahan, maka minat beli konsumen pada produk brand Wardah juga mengalami kenaikan sebesar 0,196 .

\section{b. Uji t}

Tabel 2. Hasil Uji t

\begin{tabular}{lll}
\hline Variabel & T & Sig. \\
\hline Citra Merk $\left(\mathrm{X}_{1}\right)$ & $-0,966$ & 0,336 \\
Kualitas Produk $\left(\mathrm{X}_{2}\right)$ & 3,019 & 0,003 \\
Media Sosial $\left(\mathrm{X}_{4}\right)$ & 2,037 & 0,044 \\
Harga $\left(\mathrm{X}_{3}\right)$ & 2,286 & 0,024 \\
\hline
\end{tabular}

Sumber : Data primer yang diolah (2021) 
Menurut hasil uji t, maka didapatkan hasil sebagai berikut:

1. Variabel $X_{1}$ menunjukkan $t$ hitung sebesar -0,966 dengan nilai sig sebesar $0,336 \geq 0,05$. Artinya hipotesis ditolak, sehingga tidak berpengaruh positif terhadap minat beli.

2. Variabel $X_{2}$ menunjukkan hasil sebesar 3,019 dengan nilai sig 0,003 $\leq$ dari 0,05 . Sehingga hipotesis diterima dan berpengaruh positif terhadap minat beli.

3. Variabel $X_{3}$ menunjukkan penghitungan sebesar 2,037 dengan nilai sig $0,044 \leq$ dari 0,05 yang artinya hipotesis terbukti dan berpengaruh positif terhadap minat beli

4. Variabel $X_{4}$ menunjukkan $t$ hitung sebesar 2,286 dengan nilai sig $0,024<$ dari 0,05 yang artinya hipotesis berlaku dan mempengaruhi minat beli.

2. Pengaruh Kualitas Produk Terhadap Minat Beli

\section{c. Uji F}

Berdasarkan uji output SPSS, maka dapat ditemukan bahwa nilai $f$ hitung adalah 14,280 dengan nilai sig sebesar $0,000 \leq$ dari 0,05 yang artinya citra merek, kualitas produk, media sosial dan harga mempengaruhi minat beli konsumen pada produk kosmetik Wardah.

\section{Pembahasan}

1. Pengaruh Citra Merek Terhadap Minat Beli Hasil uji regresi, maka variabel citra merek $\left(X_{1}\right)$ tidak berpengaruh positif atau signifikan pada minat beli produk kosmetik brand Wardah. Calon konsumen tidak sekadar berminat pada produk brand Wardah yang memiliki citra merek "Halal". Hal ini tidak sejalan dengan penelitian yang telah dilakukan oleh Endro Arifin dan Achmad Fachrodji (2015) di mana hasil penelitian dari variabel citra merek berpengaruh secara signifikan terhadap minat beli.

Berdasarkan hasil uji regresi, maka variabel kualitas produk $\left(X_{2}\right)$ terdapat pengaruh yang positif atau signifikan pada aspek kecenderungan membeli produk kosmetik brand Wardah. Artinya adalah kualitas produk telah mempengaruhi calon konsumen untuk melakukan memiliki minat beli terhadap produk kosmetik brand Wardah. Hal ini membuktikan penelitian terdahulu yang telah dilakukan oleh Basrah Saidani dan Samsul 
Arifin (2012) dimana variabel kualitas produk berpengaruh secara langsung terhadap minat beli konsumen.

\section{Pengaruh Media Sosial Terhadap Minat Beli}

Berdasarkan hasil penghitungan regresi, maka variabel media sosial $\left(X_{3}\right)$ berpengaruh positif atau menjadi faktor penting terhadap minat beli konsumen untuk produk kosmetik brand Wardah. Artinya adalah media sosial mempengaruhi calon konsumen atau masyarakat terhadap minat beli. Hal ini sependapat dengan analisis data yang telah dilakukan oleh Deru R. Indika dan Cindy Jovita (2017) dimana media sosial memiliki korelasi kuat dalam minat beli konsumen.

\section{Pengaruh Harga Terhadap Minat Beli}

Bersumber pada analisa regresi, maka variabel harga $\left(X_{4}\right)$ mempunyai pengaruh positif pada minat beli produk kosmetik brand Wardah. Artinya adalah harga telah mempengaruhi calon konsumen dalam memiliki minat beli. Hal ini membuktikan penelitian terdahulu yang telah dilakukan oleh Muhammad Fakhru Rizky NST dan Hanifa Yasin (2014) dimana variabel harga berpengaruh positif terhadap keinginan untuk membeli dari konsumen.
Aaker dan Biel (1993) berpendapat, citra merek merupakan penilaian konsumen mengenai merek atau brand tersebut pada sebuah pasar. Antar konsumen memiliki penilaian berbeda terhadap suatu merek namun merek yang sudah terkenal memiliki citra baik pasti akan lebih banyak dikenal oleh masyarakat. Bagi Kotler (2009), citra sebuah merek adalah pandangan masyarakat terhadap produk ataupun perusahaan. Gambaran dari sebuah merek yang baik sangatlah efektif dalam membangun persepsi masyarakat terhadap produk ataupun perusahaan tersebut karena memiliki karakter yang kuat, tidak mudah ditiru oleh pesaing dan dapat memberikan pengalaman emosional yang menyenangkan dalam benak konsumen. Menurut Tjiptono (2011) citra merek merupakan gabungan dari beberapa bagian yang menjadi persepsi konsumen selama berjalannya waktu dan wujud nyata dari pengalaman yang dimiliki konsumen baik secara riil maupun lewat perantara pada sebuah merek. Sedangkan definisi operasional menurut Keller (2008) citra merek adalah penggambaran dari konsumen mengenai suatu brand atau merek sebagai cerminan dari bagian pada brand yang ada dalam benak konsumen (Dikutip Danny Alexander Bastian, 2014).

\section{Kutipan dan Acuan}

\section{Citra Merek (X1)}

\section{Kualitas Produk (X2)}


Menurut Kotler dan Keller (2009) yaitu merupakan bukti nyata dari sebuah produk ataupun jasa yang memberikan pengalaman melebihi ekspektasi pelanggan sehingga pelanggan berkeinginan untuk melakukan pembelian pada produk. Kemudian pendapat dari Kotler dan Amstrong (2008) adalah media untuk mendapatkan kesan yang baik dalam benak pelanggan dan sebagai senjata utama dalam pemasaran sebagai pengalaman berharga untuk pelanggan dalam menggunakan produk. Menurut Nasution (2005) definisi kualitas produk yaitu adanya keselarasan antara produk, tim saling bersinergi, proses dan pekerjaan dan lingkungan perusahaan yang pada akhirnya melampaui harapan dari pelanggan. Selanjutnya yaitu,Tjiptono (2012) mengungkapkan kualitas produk merupakan produk dengan mutu yang diharapkan oleh konsumendan memuat kebutuhan pelanggan pada produk tersebut. Sedangkan definisi operasional menurut Kotler dan Armstrong (2008) yaitu sebagai sarana dimana pemasar menanamkan kesan tertentu pada benak pelanggan. Kinerja produk dan berbagai aspek yang ada didalamnya sangat berdampak pada kualitas produk tersebut, maka dari itu produk yang berkualitas sangat dapat diukur dengan nilai produk itu sendiri serta yang akan menjadi salah satu pertimbangan konsumen dalam minat pembeliannya, (Dikutip Panji Surachman, 2015).

\section{Media Sosial (X3)}

Pendapat dari Philip Kotler dan Kevin Lane Keller (2016) tentang social media adalah merupakan sarana dalam bertukar informasi baik berupa pesan teks, suara, gambar dan rekaman gambar hidup dari satu individu ke individu lainnya atau individu ke kelompok maupun sebaliknya. Caleb T. Carr dan Rebecca A. Hayes (2015) berpendapat bahwa social media merupakan media yang penggunannya lewat internet untuk berkomunikasi antar individu baik secara real time ataupun terjeda, secara luas maupun individual. Bagi Joyce Kasman Valenza (2014) media sosial adalah sarana jaringan komunikasi elektronik yang memudahkan seseorang untuk berkomunikasi tanpa adanya batas ruang dan waktu dengan kelompoknya. Sedangkan definisi operasional menurut R. Sudiyatmoko (2015) media sosial adalah sarana online dengan menggunakan internet yang penggunaanya untuk berbagi, berpartisipasi dan berkomunikasi satu dengan yang lainnya secara virtual. Pergerakan media sosial sangat cepat, namun pada perjalanannya juga mengurangi intensitas komunikasi antar individu di dunia nyata karena terkonsentrasi pada media sosial. (Dikutip Resti Punkasaningtyas, 2017) 


\section{Harga (X4)}

Kotler dan Armstrong (2010) mengungkapkan, harga merupakan nilai yang harus ditukarkan oleh konsumen atas manfaat yang diperoleh dari suatu barang ataupun jasa. Biasanya alat tukar yang digunakan berupa uang. Menurut Basu Swastha (2010) harga adalah besarnya biaya yang ditukarkan berupa barang atau uang dengan beberapa gabungan antara barang serta pelayanan yang didapatkan. Menurut Tjiptono (2007) harga yaitu sebagai satuan uang yang digunakan untuk memperoleh kepemilikan atas sesuatu. Sedangkan definisi operasional dari harga bagi Kotler dan Amstrong (2008) adalah besaran nilai yang ditujukan untuk pelanggan dalam menikmati manfaat dari penggunaan produk dan atau jasa. Harga menjadi tolok ukur nilai suatu produk dan dan memberikan pertimbangan tersendiri bagi konsumen dalam menentukan pilihan. (Dikutip Rina Sukmawati, 2017)

\section{Minat beli (Y)}

Schiffman dan Kanuk (2004) berkata bahwa minat beli merupakan pengaruh dari luar, kebutuhan, pemahaman akan suatu produk dan evaluasi alternatif yang pada akhirnya memunculkan minat pada benak konsumen untuk membeli produk. Pengaruh lainnya dari luar dapat berupa iklan atau marketing dari perusahaan produk tersebut ataupun dari dorongan lingkungan sekitar. Menurut Pramono (2012) minat beli adalah langkah konsumen dalam menentukan satu pilihan alternatif dari beberapa merek yang paling mendekati dengan kebutuhan dan keinginan konsumen tersebut. Pendapat dari Kotler dan Keller (2009) minat beli merupakan respon dari pelanggan pada sebuah produk dan memutuskan untuk melaksanakan pembelian. Sedangkan definisi operasional menurut Assael (2001) adalah kecenderungan pelanggan dalam mempertimbangkan sebuah merek dalam melakukan pembelian dengan mengukur tingkat probabilitas pelanggan membuat keputusan untuk membeli. Minat beli membuat konsumen cenderung untuk memilih sebuah merek dari beberapa merek yang ada dalam pertimbangannya. (Dikutip Arief Adi Satria, 2017).

\section{PENUTUP}

\section{Kesimpulan}

Berdasarkan hipotesis, variabel citra merek, kualitas produk, harga dan media sosial memiliki pengaruh yang signifikan terhadap minat beli konsumen pada produk brand Wardah. Namun dalam proses penelitian, peneliti menemukan bahwa ada variabel bebas yang tidak mempengaruhi variabel terikat. Variabel yang mempunyai dorongan positif atau signifikan terhadap variabel minat beli (Y) adalah variabel kualitas produk, media sosial dan harga, serta variabel citra merek 
tidak berpengaruh positif terhadap keinginan konsumen membeli produk kosmetik brand Wardah. Bila keempat variabel tersebut berjalan secara bersamaan, maka hasilnya positif atau mempengaruhi minat beli pada produk kecantikan brand Wardah.

\section{Saran}

\section{DAFTAR PUSTAKA}

Satria, Arief Adi. (2017). Pengaruh Harga, Promosi dan Kualitas ProdukTerhadap Minat Beli Konsumen pada Perusahaan A-36. Jurnal Manajemen dan Start-Up Bisnis. Fakultas Manajemen dan Bisnis: Universitas Ciputra Surabaya

Punkasaningtyas, Resti. (2017). Hubungan Penggunaan Media Sosial dengan Kualitas Tidur, Kestabilan Emosi dan Kecemasan Sosial pada Remaja di SMAN 20 Surabaya. Fakultas Keperawatan. Surabaya: Universitas Airlangga

B. Alexander, D. (2014). Analisa Pengaruh Citra Merek (Brand Image) dan Kepercayaan Merek (Brand Trust) Terhadap Loyalitas Merek (Brand Loyalty) ADES PT. Ades Alfindo Putra Setia. Jurnal Manajemen Pemasaran Petra, 2(1), 1-9.

Martono, M. S. S. I. (2014). Analisis Pengaruh Kualitas Produk, Harga Dan Promosi Terhadap Minat Beli Konsumen Produk Batik Sendang Duwur Lamongan. Jurnal Ilmu Manajemen, 2(2), 687-699.
Berdasarkan hasil pada penelitian ini Citra merk tidak berpengaruh signifikan maka peneliti menyarankan kepada perusahaan agar lebih membangun citra merek yang lebih baik dan berkesan supaya menjadi "top of mind" pada benak konsumen dan membuat konsumen selalu berpendapat bahwa produk Wardah memiliki produk yang baik dan menjadikan pilihan utama dalam memilih kosmetik.

https://jurnalmahasiswa.unesa.ac.id/ index.php/jim/article/download/102 02/9971

Nurhayati, S. (2017). Pengaruh citra merek, harga dan promosi terhadap keputusan pembelian handphone samsung di yogyakarta. JBMA - Vol. IV, No. 2, September 2017 ISSN : 22525483, IV(2), 60-69.

Ong, I. A., \& Sugiharto, S. (2013). Analisa Pengaruh Strategi Diferensiasi, Citra Merek, Kualitas Produk Dan Harga Terhadap Keputusan Pembelian Pelanggan Di Cincau Station Surabaya. Manajemen Pemasaran, 2(2), 1.

Pradhana, A. (2015). Analisis Pengaruh Kualitas Produk dan Kualitas Layanan Terhadap Loyalitas Pelanggan Dengan Kepuasan Pelanggan Sebagai Intervening (Studi Kasus pada Lumpia Mba Lien Semarang). Skripsi, Fakultas Ekonomika dan Bisnis, Universitas Diponegoro Semarang.

Setiawati, Mila; Aini, Yulfita; Aida, W. (2015). Pengaruh Media Sosial Terhadap Minat Beli Konsumen (Studi Kasus mahasiswa Manajemen Universitas 
Pasir Pengaraian). Fakultas Ekonomi, Universitas Pasir Pengaraian, 13.

Stephen, A. T. (2016). The role of digital and social media marketing in consumer behavior. Current Opinion in Psychology, 10, 17-21. https://doi.org/10.1016/j.copsyc.201 5.10 .016

Sulistyawati, P. (2011). Analisis Pengaruh Citra Merek Dan Kualitas Produk Terhadap Keputusan Pembelian Laptop Merek Acer diKota Semarang. Manajemen, 1-25.

Sutrisno, N., \& Haryani, A. D. (2017). Influence of Brand and Product Quality on Customer's Buying Decision in South Cikarang Bekasi Regency. Jurnal Lentera Bisnis, 6(1), 85.

https://doi.org/10.34127/jrlab.v6i1.1 69 